\title{
Tether Containing UBX Domain For GLUT4
}

National Cancer Institute

\section{Source}

National Cancer Institute. Tether Containing UBX Domain For GLUT4. NCI Thesaurus. Code C70993.

Tether containing UBX domain for GLUT 4 protein (553 aa, 60 kDa) is encoded by the human ASPSCR1 gene. This protein is involved in the regulation of glucose transport and sequestration. 